\title{
BOLESŁAW SULIK - ŁĄCZNIK Z LONDYNU
}

\author{
Krzysztof TARKA (Opole)
}

W marcu 1976 roku „Orfeusz”, charakteryzując na użytek Służby Bezpieczeństwa swojego znajomego, stwierdził:

Postać Bolesława Sulika, dziennikarza, scenarzysty, tłumacza, zasługuje ze wszech miar na zainteresowanie ze względu na jego rolę w podtrzymywaniu bliskich kontaktów między krajowym środowiskiem opozycyjnym a zachodnimi ośrodkami dywersji ideologicznej ${ }^{1}$.

Bolesław Sulik urodził się 8 kwietnia 1929 roku w Toruniu. W życiorysie napisanym przed pierwszą podróżą do Polski w połowie lat 60. i złożonym w Konsulacie Generalnym PRL w Londynie podał, że jego ojciec, Nikodem, był oficerem Wojska Polskiego. W przededniu drugiej wojny światowej rodzina Sulików mieszkała w Sarnach na Polesiu. W 1939 roku ojciec Bolesława nie wrócił z frontu do domu. W listopadzie Aniela Sulik wraz z dziećmi przeniosła się do Białegostoku. Gdy w marcu 1940 roku została aresztowana przez NKWD i deportowana w głąb Związku Sowieckiego, jedenastoletni Bolesław wraz ze starszymi siostrami wyjechał do rodziny ojca we wsi Stara Kamienna koło Dąbrowy Białostockiej. Tutaj spędził lata wojny pomagając przy pracy na roli. W sierpniu 1946 roku nielegalnie wyjechał z Polski. Poprzez Czechosłowację i Austrię dotarł do Włoch, gdzie jego ojciec, generał brygady, był dowódcą 5. Kresowej Dywizji Piechoty w 2. Korpusie Polskim. Bolesław wstąpił do wojska i niebawem wraz z oddziałami polskimi został ewakuowany do Wielkiej Brytanii.

\footnotetext{
${ }^{1}$ Archiwum Instytutu Pamięci Narodowej (dalej: AIPN), 01789/323, Bolesław Sulik — charakterystyka z 9 III 1976 r. (źródło „Orfeusz”). Jak wynika z zachowanych dokumentów SB pod pseudonimem „Orfeusz” krył się Zygmunt Dzięciołowski, filolog, tłumacz, jeden z przywódców strajku studentów na Uniwersytecie Warszawskim w 1968 roku. Po aresztowaniu pozyskany do współpracy przez Wydział III Komendy Milicji Obywatelskiej m. st. Warszawy. W 1973 roku przejęty przez Departament I MSW (wywiad). Wykorzystywany był do inwigilacji paryskiej „Kultury”, Radia Wolna Europa, „Aneksu”, pomarcowej emigracji w Szwecji i Danii, a także przerzutu literatury bezdebitowej do Polski; zob.: Nota biograficzna Z. Dzięciołowskiego w: Marzec 1968 w dokumentach MSW, t. 2, Kronika wydarzeń, cz. 1, red. nauk. i wstęp F. Dąbrowski, P. Gontarczyk, P. Tomasik, Warszawa 2009, s. 657.
} 
W 1948 roku zdał maturę i rozpoczął studia ekonomiczne na uniwersytecie w Cambridge, które przerwał po roku. Przez jakiś czas pracował dorywczo jako niewykwalifikowany robotnik w restauracjach Lyons'a i w fabryce kiełbasek Walls'a, po czym rozpoczął studia humanistyczne na North Western Polytechnic w Londynie, których jednak nie ukończył. Następnie pracował w wytwórni kołder „Limba”. W drugiej połowie lat 50. Sulik nawiązał współpracę z różnymi czasopismami emigracyjnymi. Wchodził w skład redakcji „Konturów”, młodzieżowej kolumny drukowanej na łamach „Dziennika Polskiego i Dziennika Żołnierza". Był również członkiem zespołu redakcyjnego miesięcznika „Kontynenty”. Jego pasją stał się jednak film. W 1959 roku ukończył kurs techniki filmowej w London School of Film Technique. Następnie był jednym $\mathrm{z}$ redaktorów angielskiego periodyku krytyki filmowej „Definition”. Zamieszczał recenzje filmowe w lewicowym tygodniku angielskim „Tribune”. Współpracował z British Film Institute, wygłaszając referaty o filmie w dyskusyjnych klubach filmowych oraz na kursach oświatowych dla dorosłych. Jako montażysta amatorsko zajmował się także twórczością filmową ${ }^{2}$.

„Orfeusz” donosił Służbie Bezpieczeństwa, że Sulik od początku pobytu w Wielkiej Brytanii „wyjątkowo źle adaptował się do nowej sytuacji. Bardzo źle czuł się wśród polskiej emigracji, buntował się przeciw jej politycznemu konserwatyzmowi”. Po Październiku 1956 roku zdecydowany był nawet na powrót do kraju, przed czym miała go powstrzymać żona. W następnych latach kontakty Sulika z Ambasadą Polskiej Rzeczpospolitej Ludowej oraz Instytutem Kultury Polskiej w Londynie pogłębiły jeszcze jego konflikt ze środowiskiem emigracyjnym. W ,polskim” Londynie powszechnie uważano go za ,,agenta Warszawy”, „ubeka” czy „sprzedawczyka”. Równocześnie Sulik nawiązał dobre kontakty z pisarzami i filmowcami, którzy przyjeżdżali z Polski do Wielkiej Brytanii. Poznał także kilku czołowych później polityków brytyjskiej Labour Party (Michael Foot, Anthony W. Benn) $)^{3}$.

W końcu lat 50. Sulikiem zainteresował się wywiad PRL. Początkowo tylko obserwowano jego działalność w środowisku „młodych” emigrantów. W maju 1962 roku, Mirosław Romaniuk z wydziału polonijnego Konsulatu Generalnego PRL w Londynie (w rzeczywistości oficer wywiadu) kusił Sulika nagrodą Stowarzyszenia Dziennikarzy Polskich za książkę Polacy w Wielkiej Brytanii, która rok wcześniej ukazała się w „Bi-

${ }^{2}$ Odpis życiorysu B. Sulika z akt Konsulatu Generalnego w Londynie trafił do wywiadu; zob.: AIPN, 01789/323, Odpis życiorysu „Bassa”. N. Sulik był przedwojennym podpułkownikiem. W drugiej połowie lat 30. dowodził batalionami Korpusu Ochrony Pogranicza na Wołyniu, Nowogródczyźnie i Polesiu. W grudniu 1939 roku został dowódcą wojewódzkim Służby Zwycięstwu Polski, a następnie komendantem Związku Walki Zbrojnej w Okręgu Wilno. Aresztowany w kwietniu 1941 roku przez NKWD. Po zwolnieniu z więzienia wstąpił do armii gen. W. Andersa. Po wojnie pozostał na emigracji. Zmarł w Londynie w 1954 roku; zob.: K. Filipow, Generat Nikodem Sulik: (Kamienna Stara 1893-Londyn 1954), Białystok 1996; W. K. Roman, Za Polskę do celi śmierci: śledztwo i proces Nikodema Sulika, Toruń 2001. Firma „Limba” była własnością szwagra B. Sulika - Kazimierza Sabbata; zob.: J. K. Danel, Kazimierz Sabbat (1913-1989) - polityk i maż stanu, Niepodległość 2000/2001 t. 51 (t. 31 po wznowieniu), s. 19.

3 AIPN, 01789/323, Bolesław Sulik — charakterystyka z 9 III 1976 r. (źródło „Orfeusz”). W 1949 r. B. Sulik wstąpił do Labour Party. Jak wspominał kilkanaście lat później, życie polityczne na emigracji już wtedy wydawało mu się „,łławiąco ciasne i jałowe”. „Wybór pomiędzy młodymi endekami, młodymi socjalistami, młodymi piłsudczykami, dla mnie, który z Kraju nie zdążył, na szczęście, wynieść żadnych partyjnych lojalności, nie ofiarowywał niczego, byłby decyzją udziału w bezsensownej kabale". Na przełomie lat 50. i 60. Sulik związał się z angielską „,nową lewicą" i ruchem antynuklearnym; zob.: B. Sulik, Dwie twarze emigranta, Kronika 1966 nr 39, s. 18-19. 
bliotece «Kultury»”! Nagrodę Sulik miał osobiście odebrać w kraju. Za propozycją nie krył się plan werbunku. Tajnym służbom chodziło jedynie o doraźne działania rozbijające emigrację polityczną. Sulik obawiał się, że wizyta nad Wisłą pogłębiłaby jego izolację w środowisku emigracyjnym i utrwaliła wizerunek „reżimowca”, choć nie wykluczył przyjazdu do Polski w przyszłości, np. jako korespondent jednej z angielskich gazet ${ }^{4}$.

Od pierwszego numeru z 17 listopada 1962 roku Sulik współpracował z tygodnikiem „Kronika”, redagowanym przez znanego w polskim Londynie wydawcę i księgarza Bolesława Świderskiego (pismo było finansowane z funduszu operacyjnego Departamentu I MSW). Do końca lat 60. niemal w każdym numerze „Kroniki” publikował recenzje filmowe i teatralne, pisał reportaże o tematyce sportowej, dał się również poznać jako publicysta polityczny ${ }^{5}$.

We wrześniu 1965 roku Sulik po raz pierwszy po dziewiętnastu latach przyjechał do Polski. Odwiedził wówczas rodzinne strony ojca. Podsumowując swoje wrażenia z wizyty w kraju stwierdził:

Dzisiejsza Polska jest krajem przedziwnych paradoksów, krajem wielkich osiągnięć i dotkliwych bolączek społecznych. Porównywanie jej z Polską przedwojenną jest ćwiczeniem jałowym, nie na temat. Co najwyżej możemy powiedzieć, że jest lepsza, bo nowocześniejsza, bo nadrobiła część dystansu, jaki dzieli nasz kraj od uprzemysłowionych państw Zachodu. Nie myślę też by na miejscu było pytanie, czy się ta Polska ,podoba" czy też nie. W ostatecznym rachunku, Polacy zamieszkali za granicą, a może i ci w Polsce, podzielą się na tych, którzy chcą być tam, chociażby w sensie czysto symbolicznym, obecni, chcą współuczestniczyć w przemianach narodu, mieć stawkę w jego przyszłość, i na tych, którzy odwracają się od niej plecami ${ }^{6}$.

Rok później Sulik był gościem Kongresu Kultury Polskiej w Warszawie. Wspominając udział w obradach Polaków z zagranicy pisał:

Po prostu byliśmy obecni - i obecności tej nie sposób odmówić symbolicznego znaczenia. Podejmowani byliśmy z wielką serdecznością i gościnnością, jako widomy dowód prawdy, że kultura polska nie ma geograficznych granic, że każdy Polak, bez względu na to gdzie mieszka i jaki posiada paszport, jeżeli tylko ma wolę uczestniczyć w życiu narodu, tym samym ma to prawo ${ }^{7}$.

${ }^{4}$ AIPN, 01789/323, Raport płk. S. Lipowskiego z 28 IV 1976 r. o wyrażenie zgody na przeprowadzenie rozmowy operacyjnej z figurantem sprawy wstępnej kryptonim „Bass”. Na początku 1962 roku w jednym z naukowych czasopism w Polsce ukazała się pozytywna recenzja książki Czaykowskiego i Sulika; zob.: J. Żurawicka, Przeobrażenia emigracji polskiej w Anglii, Kultura i Społeczeństwo 1962 nr 1, s. 216-222.

${ }^{5}$ Londyński zespót redakcji „Kroniki”, Kronika 1967 nr 37, s. 4-5. W pierwszym numerze tygodnika Sulik opublikował recenzję filmu Nóż $w$ wodzie w reżyserii Romana Polańskiego (Kronika 1962 nr 1, s. 7). Szerzej na temat „Kroniki” i współpracy Świderskiego z wywiadem PRL zob.: K. Tarka, Jest tylko jedna Polska. Bolestaw Świderski - emigrant w stużbie Polski Ludowej, Pamięć i Sprawiedliwość 2007 nr 1(11), s. 273-307; K. Tarka, Mackiewicz i inni. Wywiad PRL wobec emigrantów, Łomianki 2007, s. 196-250.

${ }^{6}$ B. Sulik, Znaszli ten kraj?, Kronika $1965 \mathrm{nr}$ 49, s. 1, 3; przedruk w: Polska przemienionych kołodziejów. Zbiór artykułów i reportaży wspótpracowników londyńskiej „Kroniki”, pod red. B. Świderskiego, Londyn 1968, s. 246-251.

${ }^{7}$ B. Sulik, Kongres Kultury Polskiej, Kronika 1966 nr 44, s. 4; cz. 2: nr 46, s. 5 (Polska przemienionych kołodziejów, s. 266-276). Zob. też: W. Lewandowski, Zobaczyć Polskę z bliska. O okolicznościach i skutkach wycieczki emigracyjnych literatów do kraju, [w:] Życie literackie drugiej emigracji niepodległościowej, t. 2, red. B. Czarnecka i J. Kryszak, Toruń 2004, s. 59, 60, 69. 
Sulik nie chciał się „odwracać plecami”, chciał „uczestniczyć”. W następnych latach wielokrotnie przyjeżdżał do kraju.

Na początku lat 70. ,bezpieka” poważniej zaczęła się interesować emigracyjnym publicystą. 4 marca 1971 roku z Sulikiem rozmawiał pułkownik Tadeusz Piwiński „Adams” zatrudniony „,pod przykryciem” jako kierownik wydziału polonijnego w Konsulacie Generalnym PRL w Londynie (była to ich druga rozmowa). Pretekstem do spotkania stały się częste wizyty „Bassa” (pseudonim nadany Sulikowi przez wywiad) w kraju. Niebawem Sulik ponownie wyjeżdżał do Polski na stypendium Towarzystwa Łączności z Polonią Zagraniczną „Polonia”. Peerelowski „dyplomata” dopytywał się o jego kontakty z Radiem Wolna Europa. Sulik odżegnywał się od współpracy z monachijską rozgłośnią. Przyznał natomiast, że o poczynionych w kraju spostrzeżeniach $\mathrm{w}$ towarzyskich rozmowach informował londyńskiego korespondenta RWE Zbigniewa Racięskiego oraz wydawcę Polonia Book Foundation Andrzeja Stypułkowskiego. Na podstawie jego relacji Racięski sporządzać miał raporty dla „Wolnej Europy”. Według Sulika, Stypułkowski utrzymywał tylko doraźne kontakty z RWE, natomiast współpracował z wywiadem amerykańskim. „Bass” dodał, iż RWE oraz paryska „Kultura” były bardzo zainteresowane utworzeniem na emigracji ,nowej lewicy”. Jerzy Giedroyc namawiał profesora Leszka Kołakowskiego, znanego filozofa i partyjnego rewizjonistę, który w 1968 roku wyjechał z Polski, aby stanął na czele nowego ruchu. W Londynie w organizację ,nowej lewicy” zaangażował się również były polityk PPS Adam Ciołkosz. Sulik poinformował także Piwińskiego o przebiegu wizyty w Londynie reżyserów Jerzego Skolimowskiego i Andrzeja Wajdy. Sam dopytywał się natomiast o sytuację w kraju, a zwłaszcza o pozycję I sekretarza KC PZPR Edwarda Gierka. Jako współpracownik angielskiego tygodnika „The Observer” chciał lepiej poznać kulisy wydarzeń w kraju. Chwalił się, że jego artykuły o niedawnych strajkach w Polsce zostały wysoko ocenione przez kierownictwo pisma. Piwiński przypomniał mu, że swoją rosnącą pozycję w środowisku dziennikarskim zawdzięcza temu, że otrzymał wizę i mógł przyjechać do Polski. Oficer wywiadu oczekiwał w zamian rewanżu i pomocy w różnych sprawach. Sulik chciał się również spotkać z nowym ambasadorem PRL nad Tamizą, Arturem Starewiczem. Piwiński oceniał, że

\begin{abstract}
S[ulik] ma duże ambicje dziennikarskie oraz filmowe, te ostatnie tego typu, że z krytyka filmowego chciałby wejść do filmu jako scenarzysta. Pierwszym etapem poważniejszym jest jego obecna współpraca z Skolimowskim, następna będzie z Wajdą, kolejna z Polańskim - a więc z grupą reżyserów liczących się aktualnie w czołówce europejskiej a nawet światowej. W perspektywie zamierza się usamodzielnić $\mathrm{w}$ tym zakresie ${ }^{8}$.
\end{abstract}

Sulik żalił się, że Skolimowski wykorzystywał go finansowo. Twierdził, że reżyser ,jest bardzo czuły na pieniądze i w tych sprawach bezlitosny”. Oficer wywiadu uważał „Bassa” za wartościowego kandydata na tajnego współpracownika. W notatce służbowej ze spotkania zaznaczył, iż informacje jakie uzyskał od Sulika ,wskazują na jego operacyjne możliwości w interesujących nas ośrodkach”. Dodał jednak, iż Sulik ,,jest w dość trudnej sytuacji rodzinnej”: jedna z jego sióstr była żoną przewodniczącego Egzekutywy Zjednoczenia Narodowego (,emigracyjnego premiera”) Kazimierza Sabbata, a druga — znanego działacza emigracyjnego z Manchesteru Jarosława Żaby ${ }^{9}$.

Dwa tygodnie później, 18 marca 1971 roku, z Sulikiem rozmawiał „Służewski” (prawdopodobnie oficer wywiadu zatrudniony na etacie w Konsulacie Generalnym

${ }^{8}$ AIPN, 01789/323, Notatka służbowa „Adamsa” dot. spotkania z Bolesławem Sulikiem w dn. 4 III 1971 r.

${ }^{9}$ Tamże; zob. też: tamże, Raport płk. S. Lipowskiego z 28 IV 1976 r. 
PRL). „Bass” załatwiał sprawy związane z wyjazdem do Polski na stypendium Towarzystwa „Polonia”. W kraju miał zebrać materiały do książki o zmianach społecznych w Polsce Ludowej. Swój pobyt zamierzał przedłużyć do sześciu miesięcy. W tej sprawie kontaktował się już z MSZ i Polską Agencją „Interpress”. Chwalił się, że półroczne stypendium wynosić ma 30 tys. złotych. Sulik opowiadał też „Służewskiemu” o rozmowie z Gustawem Gottesmanem z tygodnika „Literatura”, który wracał do Polski ze stypendium w Sussex University w Brighton. Warszawski dziennikarz chciał zostać redaktorem naczelnym dwutygodnika „Współczesność”. Sulik zachwalając swojego znajomego twierdził, że jest on „fachowcem dużej klasy, jeśli chodzi o dziennikarstwo”. Dodał, że Gottesman ma także wielu wpływowych „kumpli” oraz „ogromne znajomości” wśród czołowych brytyjskich polityków z Partii Pracy, którzy zapraszają go na prywatne obiady i kolacje ${ }^{10}$. Takie informacje mogły być bardzo przydatne do wytypowania przez wywiad kandydata do werbunku.

Podczas kolejnego spotkania, 11 maja 1971 roku, Sulik opowiadał Piwińskiemu o rozmowie z Ludwikiem Łubieńskim z RWE, który kilka dni wcześniej przyjechał z Monachium do Londynu. Na prywatnej kolacji Łubieński wyjawił Sulikowi, że to on „wynalazł” Andrzeja Czechowicza i wciągnął go do pracy w „Wolnej Europie” (dwa miesiące wcześniej „as” peerelowskiego wywiadu wrócił po „wykonaniu zadania” do Polski) ${ }^{11}$. Łubieński opowiadał mu również o konflikcie Jana Nowaka-Jeziorańskiego z niektórymi pracownikami Rozgłośni Polskiej RWE. Do oponentów dyrektora sekcji polskiej należeć miał m.in. pisarz Tadeusz Nowakowski. Sulik donosił także „konsulowi” o pobycie w Londynie studenta warszawskiej Akademii Sztuk Pięknych Andrzeja Dudzińskiego wraz z żoną (córką pisarza Stanisława Dygata). Dudziński zarabiał wykonując karykatury dla pism pornograficznych. Materialnie pomagał mu również Sulik. Według „Bassa” Dudzińskim interesowała się londyńska placówka RWE. Na podstawie tych informacji oficer wywiadu stwierdził w raporcie dla przełożonych:

Dudziński zasługuje na nasze zainteresowanie w kontekście operacyjnego wykorzystania $\mathrm{z}$ uwagi na dotarcie do środowisk i grup będących w naszym operacyjnym zainteresowaniu $^{12}$.

Do Sulika dotarła też informacja, że amerykańskie organizacje żydowskie finansują produkcję filmu na podstawie książki Aleksandra Sołżenicyna Krąg pierwszy. Reżyserem filmu był Aleksander Ford, który po Marcu'68 wyemigrował do Danii. Za kilka dni Sulik wyjeżdżał do Polski na zaproszenie „Interpressu” i Towarzystwa „Polonia”. Podczas pobytu w kraju zamierzał m.in. współpracować z Jerzym Skolimowskim i Jerzym Gruzą nad scenariuszem do filmu, do którego zdjęcia miały być kręcone podczas olimpiady w Monachium. Film pokazywać miał różne grupy polskich emigrantów wplątanych w działalność kryminalną i polityczną. Sulik zachęcająco dodał, że w filmie można by pokazać ,fragment dywersyjnej działalności RWE”. Piwiński sugerował $\mathrm{mu}$, aby przy realizacji filmu wykorzystać materiały i informacje przekazane prasie przez Czechowicza, z którym realizatorzy filmu mogliby dodatkowo porozmawiać i skonsultować fragmenty dotyczące monachijskiej rozgłośni. Sulik chwalił się, że

${ }^{10}$ Tamże, Odpis notatki „Służewskiego” z 22 III 1971 r. z rozmowy z red. Bol[esławem] Sulikiem. Kilka lat później Sulik wspominał, iż podczas pobytu w kraju w 1971 roku raz na miesiąc odbierał w lokalu Towarzystwa „Polonia” 3 tys. zł stypendium; zob.: B. Sulik, Osoby towarzyszace, Kultura $1977 \mathrm{nr}$ 5(356), s. 55. Na początku lat 70. przeciętna płaca w PRL wynosiła ok. 2,4 tys. zł.

${ }^{11}$ AIPN, 01789/323, Notatka służbowa „Adamsa” z przebiegu spotkania z B. Sulikiem z dn. 11 V 1971 r. Zob. też: J. Nowak-Jeziorański, Wojna w eterze, Kraków 2005, s. 601.

12 AIPN, 01789/323, Notatka służbowa „Adamsa” z dn. 11 V 1971 r. 
w londyńskich kinach wyświetlany jest film Deep End (Na samym dnie) w reżyserii Skolimowskiego. Autorami scenariusza byli Skolimowski, Gruza i Sulik. W ocenie oficera wywiadu

Sulik buduje sobie pozycję w sferach dziennikarsko-literackich angielskich. Próbuje wejść etatowo do angielskiego „Observera” [...] w tej sytuacji każdy element, który może być mu pomocny we własnej karierze może być dla nas do wygrania ${ }^{13}$.

Wykorzystując zawodowe ambicje „Bassa” proponował przełożonym stopniowo wciągać go do współpracy:

Elementów jest wiele - przy czym groźba zamknięcia mu drogi przyjazdu do Polski uniemożliwi mu zarówno karierę dziennikarską, jak i reżyserską, bo myśli i o tym, aby w przyszłości reżyserować własne filmy, jeśli jego nazwisko przyjmie się, po okresie dłuższej współpracy i na razie nieco w cieniu takich nazwisk renomowanych jak Skolimowski, Polański, Wajda znanych w światowej kinematografii ${ }^{14}$.

Oficer wywiadu uważał, że planowany przez Sulika wyjazd do Polski „daje możliwość realizowania naszych wobec niego przedsięwzięćc. Piwiński był przekonany, że Sulik domyślał się kim faktycznie był jego rozmówca:

\begin{abstract}
Moje dotychczasowe z nim spotkania — raportował pułkownik — zorientowały go dostatecznie w tym, że moje zainteresowania wykraczają poza problemy konsularne. Jego informacja o Dudzińskim, którego sprowadził i który jest jego kolegą, dane przekazywane o Gottesmanie, własnej rodzinie z obozu ,niezłomnych”, informacje o RWE i „Kulturze”, Giedroyciu świadczą, że wiedząc kim jestem wie równocześnie o tym, że przekazywane mi informacje są na użytek naszej służby, mimo że o wywiadzie nie było dotychczas mowy ${ }^{15}$.
\end{abstract}

Wydawało się, że sprawa rozwija się w dobrym — z punktu widzenia SB — kierunku. Jednak z nieznanych powodów podczas pobytu Sulika w kraju nie doszło do sugerowanej przez Piwińskiego rozmowy werbunkowej. Czyżby Centrala nie zaakceptowała planu pułkownika? W późniejszym o pięć lat raporcie na ten temat znajduje się tylko lakoniczna informacja: „Rozmowy takiej nie przeprowadzono”.

Na początku lat 70. Sulik nawiązał kontakt z ,komandosami”. Jego częste podróże na linii Londyn-Warszawa sprawiły, że stał się łącznikiem między rodzącym się środowiskiem opozycyjnym w kraju a paryską „Kulturą”. Podczas pobytu w Polsce w 1971 roku otrzymał od Adama Michnika i Jana Lityńskiego taśmę magnetofonową z zapisem spotkania Edwarda Gierka ze stoczniowcami Szczecina. Taśmę przewiózł przez granicę kuzyn Sulika, który po powrocie do Londynu przesłał ją do redakcji „Kultury”. Jeszcze w tym samym roku Giedroyc opublikował dokument Rewolta szczecińska i jej znaczenie. „Iście benedyktyńską pracę przy spisywaniu taśm wykonali Nina i Eugeniusz Smolarowie”. SB nigdy nie zorientowała się w roli jaką Sulik odegrał przy przewiezieniu taśm szczecińskich na Zachód ${ }^{17}$.

${ }^{13}$ Tamże.

14 Tamże.

15 Tamże.

16 Tamże, Raport płk. S. Lipowskiego z 28 IV 1976 r.

17 Taśmy szczecińskie [rozm. W. Orlińskiego z B. Sulikiem], Gazeta Wyborcza 2001 nr 18, s. 21; Rewolta szczecińska i jej znaczenie, oprac. E. Wacowska, Paryż 1971; A. Friszke, Czas KOR-u. Jacek Kuroń a geneza Solidarności, Kraków 2011, s. 42. O strajkach i demonstracjach na Wybrzeżu w grudniu 1970 roku Sulik pisał też na łamach londyńskiej „Kroniki”; zob.: B. Sulik, Gdańsk-Gdynia-Szczecin, Kronika 1971 nr 2, s. 1, 8. 
Początkowo ze względu na częste wizyty Sulika w Warszawie niektórzy z „komandosów” wysuwali pod jego adresem ,najróżniejszego rodzaju obiekcje”, podejrzewając go o współpracę z „,bezpieką” (,Orfeusz” kilkakrotnie słyszał tego rodzaju sugestie). W obronie Sulika stanął Michnik, który podkreślał, że Sulik ,nie miałby żadnego interesu współpracując z władzami"18.

Wydaje się, że sprawa taśm szczecińskich była swego rodzaju testem na lojalność Sulika i momentem przełomowym w jego współpracy z „komandosami”. Od tego czasu utrzymywał on bardzo bliskie kontakty z Adamem Michnikiem, Jackiem Kuroniem, Janem Lityńskim, Wiktorem Woroszylskim i Jackiem Bierezinem. Świadectwem zaufania wobec Sulika stało się zaproszenie go na bal sylwestrowy „opozycji” w 1971 roku. W rozmowie z „Orfeuszem” Sulik miał twierdzić, że „bojkot emigracji i zła opinia jaką cieszy się w tym środowisku są mu jak najbardziej na rękę. Dzięki temu udaje mu się uzyskać potężne alibi dla swoich nie bardzo akceptowanych przez władze w kraju kontaktów ze środowiskiem opozycyjnym"19.

Według „Orfeusza” Sulik był ,atrakcyjnym partnerem dla działaczy tego środowiska ze względu na łatwość poruszania się po świecie, z drugiej strony opozycja interesowała Sulika, gdyż kontakty z nią dawały mu szansę pewnej naprawy reputacji w Anglii”. Dziennikarz z Londynu pełnił rolę łącznika między rodzącym się środowiskiem opozycyjnym w kraju a paryską „Kulturą”: przekazywał informacje oraz różne materiały przeznaczone do druku. „Orfeusz” podejrzewał, że Sulik przekazał do „Kultury” artykuł Kuronia o politycznej opozycji w Polsce (o artykule słyszał od Sulika zanim został on opublikowany) oraz esej Michnika o Piłsudskim. Mógł również wystąpić w roli pośrednika, który przemycił wiersze Bierezina. Sulik należeć miał do najlepszych informatorów Jerzego Giedroycia. Każdorazowo po powrocie z Polski natychmiast dzwonił do Maisons-Laffitte przekazując najnowsze wiadomości, polecenia i prośby. Mimo że redaktor „Kultury” niejednokrotnie narzekać miał na bałaganiarstwo, brak solidności i opieszałość Sulika w załatwianiu ważnych spraw, to był on dla niego „,bezcennym źródłem wiadomości z Kraju”. Sulik odegrać miał również istotną rolę w rozbudzeniu zainteresowania opozycji w kraju ,polskim” Londynem. „W dużym stopniu” uświadomił Michnikowi i Kuroniowi, że obok paryskiej „Kultury” „na emigracji funkcjonują także inne ośrodki dywersji, które warto by wciągnąć do współpracy”. Informator zwracał również uwagę na kontakty Sulika „poza środowiskiem opozycyjnym". Do grona jego najbliższych znajomych mieli należeć: Agnieszka Osiecka, Stanisław Dygat, Andrzej Dudziński, Gustaw Gottesman, Tadeusz Konwicki, Andrzej Wajda, Krzysztof Kieślowski, Krzysztof Mętrak ${ }^{20}$.

W styczniu 1975 roku Sulik przyjechał do Polski na zaproszenie Zespołu Realizatorów Filmowych „X”. Była to jego dziewiętnasta wizyta w kraju w ciągu ostatnich dziesięciu lat! Do SB szybko dotarła informacja, że w połowie stycznia w towarzystwie Adama Ulfika, ,jednego z czołowych wichrzycieli z okresu wydarzeń grudniowo-styczniowych w stoczni im. [Adolfa] Warskiego", odwiedził żonę Edmunda Bałuki,

\footnotetext{
${ }^{18}$ AIPN, 01789/323, Bolesław Sulik — charakterystyka z 9 III 1976 r. (źródło „Orfeusz”).

${ }^{19}$ Tamże. Kilka lat później na łamach paryskiej „Kultury” Sulik wspominał sylwester 1971 roku; zob.: B. Sulik, Oblężeni, Kultura 1977 nr 1/2(352-353), s. 3-4.

${ }^{20}$ AIPN, 01789/323, Bolesław Sulik — charakterystyka z 9 III 1976 r. (źródło „Orfeusz”). Informacje przekazane przez „Orfeusza” wywiad uważał za bardzo pożyteczne, wartościowe i wiarygodne; tamże, Uwagi płk. H. Wróblewicza. Zob. też: [J. Kuroń], Polityczna opozycja $w$ Polsce, Kultura 1974 nr 11(326), s. 3-21 (przedruk: J. Kuroń, Opozycja. Pisma polityczne 1969-1989, Warszawa 2010, s. 40-57); [A. Michnik] Bartłomiej, Cienie zapomnianych przodków, Kultura 1975 nr 5(332), s. 3-21; J. Bierezin, Wam. Poezje, Paryż 1974.
} 
przywódcy strajku w Szczecinie. Sulik zamierzał też nakręcić film o strajku. Podczas rozmowy Janina Bałukowa wręczyła mu kilka swoich zdjęć z dziećmi i prosiła o przekazanie ich mężowi, który od blisko dwóch lat przebywał na emigracji. O spotkaniu Sulika z Bałukową SB poinformował Ulfik ${ }^{21}$.

Sulik wspominał, iż za każdym razem wyruszał z Warszawy do Szczecina w nastroju nerwowego podniecenia:

Inaczej mówiąc - bałem się. [...] W Warszawie czułem się zadomowionym, dorobiłem się tam setek przyjaciół i znajomych, w Warszawie istniało gniazdo dysydentów. [...] Na swój sposób, stolica była miastem otwartym, co na co dzień stwarzało poczucie bezpieczeństwa. Do Szczecina wjeżdżałem jak w miasto Dzikiego Zachodu, miasto bezprawia, które w swych podziemiach nie toleruje wścibskich intruzów. Wszystko, co słyszałem wzmacniało we mnie te paniczne, subiektywne odczucia.

Próbując dotrzeć do uczestników grudniowo-styczniowych strajków musiał też przełamać ich barierę strachu i nieufności:

Spotkani robotnicy - wspominał Sulik - traktowali mnie początkowo jako nasłanego ubeka, ,trenera”, bo któż inny przychodziłby do nich z takimi pytaniami? Jeżeli już udało mi się zyskać ich zaufanie, przynajmniej na czas pewien, opowiadali dziwy o policyjnej dżungli w jakiej żyją i rzucali oskarżenia o współpracę z policją jedni na drugich $^{22}$.

Gdy dwa tygodnie później Sulik zwrócił się o przedłużenie wizy pobytowej, w kierownictwie SB postanowiono wykorzystać ten fakt. Zgodnie z planem 4 lutego pułkownik J. Różański z Departamentu III MSW przeprowadził z Sulikiem rozmowę profilaktyczną w pomieszczeniach Wydziału Paszportów Komendy Stołecznej Milicji Obywatelskiej. Oficer SB przestrzegał go przed nawiązywaniem kontaktów z uczestnikami strajków w Szczecinie. W ten sposób zamierzał również storpedować pomysł nakręcenia filmu na ten temat. Chcąc skompromitować Bałukę i Ulfika ostrzegł Sulika, że obaj byli w przeszłości karani za przestępstwa pospolite. Sulik kurtuazyjnie podziękował za ostrzeżenie i dodał, że chyba nie wszyscy przywódcy strajku to kryminaliści. Tradycyjnie deklarował „lojalność” wobec Polski, ale już na wstępie rozmowy oświadczył, że jako dziennikarz nie może ujawniać nazwisk i swoich kontaktów w kraju. Tłumaczył esbekowi, że przedstawiając obiektywnie polskie problemy w prasie angielskiej robi dużo dobrego dla kraju. Za swoją niezależną postawę — twierdził — płacił wysoką cenę, ponieważ wśród „niezłomnych” emigrantów uważany był za „,zaprzedanego czerwonym". Dodał, że wszystkie swoje plany w czasie pobytu w Polsce omawiał z radcą ambasady Spalińskim: „Powinni o tym Panowie wiedzieć”. Powoływał się też na pozytywną ocenę ambasadora Starewicza. Podczas godzinnej wymiany zdań Sulik

${ }^{21}$ AIPN, 01789/323, Odpis notatki płk. J. Różańskiego z 8 II 1975 r. z rozmowy z ob. brytyjskim B. Sulikiem. W ocenie Sulika Ulfik „,w Komitecie Strajkowym [w 1971 r.] był postacią bodajże najbardziej niezłomną, otwarcie wrogą systemowi. [...] Jego poglądy były mieszanką naiwności i prawdziwego rozumu politycznego, owianą sentymentalnym a gorącym patriotyzmem. Był całkowicie bezkompromisowy i nieprzekupny, nie załamał się nigdy, do końca wierzył, że siła polskich robotników obali istniejący porządek"; zob.: B. Sulik, Robotnicy, Kultura $1976 \mathrm{nr}$ 10(349), s. 76-77. Innym razem Sulik wspominał, że Ulfik przyjął go bardzo nieufnie: „oglądał mój paszport brytyjski na wszystkie strony, kazał mi rozpoznać Bałukę na zbiorowym zdjęciu komitetu strajkowego". Przed wyjazdem do Polski Sulik kilkakrotnie rozmawiał z Bałuką, który mieszkał w Manchesterze. Bałuka dał mu też kontakt do swoich kolegów w Szczecinie; zob.: Taśmy szczecińskie, s. 21.

${ }^{22}$ B. Sulik, Dziura w ścianie, Kultura 1977 nr 10(361), s. 50-51. 
poskarżył się, że jest ostentacyjnie śledzony: „Panowie od paru dni za mną chodzą”. Na zakończenie oficer SB wręczył mu paszport z przedłużoną o dwa tygodnie wizą. Pułkownik Różański nie wykluczał, że Sulik mimo ostrzeżenia będzie szukał kontaktów z osobami, które brały udział w strajkach w 1970 i 1971 roku. Przypuszczał również, że emigracyjny dziennikarz może próbować wywieźć z Polski jakieś niepublikowane materiały. Proponował, aby przy wyjeździe z kraju przeprowadzić rewizję osobistą Sulika i jego bagaży ${ }^{23}$.

W roli, jaką od kilku lat odgrywał Sulik, SB zorientowała się dopiero na początku 1976 roku. Donosy „Lutusa” i „Orfeusza” oraz informacje uzyskane „techniką operacyjną" przez Departament III MSW (podsłuch?) wskazywały w przekonaniu pułkownika Sławomira Lipowskiego, naczelnika Wydziału VIII Departamentu I, że Sulik był łącznikiem między „czołowymi przedstawicielami opozycji” (Kuroniem, Michnikiem, Lityńskim) a paryską „Kulturą”:

Przywozi dyspozycje, przekazuje postulaty i prośby. Istnieje domniemanie, wynikające z analizy faktów, iż przywiózł dla „Kultury” kilka bardzo wrogich tekstów opracowanych przez krajową opozycję, wśród nich programowy artykuł Kuronia o działaniu opozycji. Z własnego mieszkania przekazał telefonicznie Giedroyciowi tekst memoriału 59-ciu. W kontaktach z grupą Kuronia-Michnika przestrzega konspiracyjnych reguł. [...] Mając takie powiązania i będąc tak zaangażowanym, a jednocześnie trzeźwym i realnym w ocenie stosunków Polska-emigracja, „Bass” prawie obojętnie może traktować stawiane mu przez „niezłomnych” zarzuty.

W ocenie SB, Sulik przyjeżdżając do Polski zamierzał „działać maksymalnie na niekorzyść jej ustroju”. Mimo „wrogiej” postawy „Bassa” oficer wywiadu planował pozyskać go do współpracy agenturalnej w celu rozpracowania obiektu „Agora” (paryska „Kultura”) oraz Andrzeja Stypułkowskiego „,i innych zaangażowanych czynnie w działaniu przeciwko naszemu ustrojowi”. Przy pomocy Sulika zamierzano również ustalić, a następnie rozpracować mechanizmy powiązań ośrodków opozycyjnych w kraju $\mathrm{z}$ „Kulturą” oraz drogi przemytu rękopisów. W szczególności liczył na zdekonspirowanie krajowych autorów publikujących na łamach „Kultury”: „Pelikana” (Zbigniew Florczak), „X.Y.Z” (Henryk Krzeczkowski), „Bartłomieja” (Adam Michnik). Aby sprawdzić szczerość Sulika funkcjonariusz SB miał go spytać o nazwiska „Stalińskiego” (Stefan Kisielewski), „Koraba” (Józef Hen), „Kołymskiego” (z dwoma ostatnimi osobami „Bass” był zaprzyjaźniony).

Pozytywna odpowiedź na pytanie, rozszyfrowanie tych pseudonimów, będzie świadczyło zarówno o prawdomówności „Bassa” jak i przełamaniu oporów. Będzie elementem wskazującym na przyjęcie propozycji współpracy.

Do przeprowadzenia rozmowy werbunkowej podczas najbliższej wizyty „Bassa” w Polsce wytypowany został pułkownik Wróblewicz. Oficer wywiadu występować miał ,z pozycji służby bezpieczeństwa MSW”. Miejsce rozmowy planowano dostosować do sytuacji. Zakładano, że będzie to apartament jednego z warszawskich hoteli: „Przy obiecującym rozwoju dyskusji — jej ciąg dalszy zostałby przeniesiony poza stolicę”. Rozmowy poprzedzić miało kilkudniowe „opracowanie figuranta” przez Biuro „B” (pion obserwacji zewnętrznej SB). Także w trakcie prowadzenia rozmów, jak i po ich zakończeniu, Sulik miał być „kontrolowany środkami techniki operacyjnej” przez Wydział III Departamentu III. Przy oporach (,,a te z pewnością wystąpią”) oficer wy-

${ }^{23}$ AIPN, 01789/323, Odpis notatki płk. J. Różańskiego z 8 II 1975 r. Rozmowę z oficerem SB i metody inwigilacji B. Sulik przedstawił w reportażu Dziura w ścianie. 
wiadu miał mu przypomnieć, że już raz (w 1971 roku) deklarował gotowość wspólnego działania przeciwko Radiu Wolna Europa. W przypadku zdecydowanego odrzucenia przez „Bassa” propozycji współpracy agenturalnej oficer wywiadu miał go zobowiązać do zachowania w tajemnicy treści rozmowy oraz uprzedzić („,bez kamuflażu”), że nie będzie mógł liczyć na otrzymywanie w przyszłości wiz wjazdowych do Polski. Kontakt miały z nim również zerwać ambasada i Instytut Kultury Polskiej w Londynie oraz instytucje krajowe. W ten sposób Sulik ,wchodząc w kolizję z interesami Kraju — nie zyska kapitału dla budowania przyszłości za granicą. Przeciwnie, zostanie ona maksymalnie nadwyrężona”. Zamierzano również kompromitować „Bassa” rozpowszechniając opinię, że „,wysługuje się reżimowi"24.

Gdy w końcu września 1976 roku brytyjska stacja telewizyjna ITV nadała film o strajku w stoczni szczecińskiej sprzed ponad pięciu lat Three Days in Szczecin (Sulik był autorem scenariusza), plan zwerbowania „Bassa” stanął pod znakiem zapytania. W szyfrogramie z Londynu „Jarema” alarmował Centralę, iż program ,jest paszkwilem na nasze kierownictwo i PRL”. Funkcjonariusz tajnych służb skrytykował również brak reakcji „Gospodarza” (ambasadora Starewicza), który nie dość, że nie podjął żadnych działań, to jeszcze zwlekał z zawiadomieniem MSZ o terminie emisji programu. Jedyne co w tej sprawie zrobił Starewicz, to ,skrytykował tylko w programie nierealistyczną postać ubowca z automatem za plecami prezydium”. Wraz z konsulem Kalinowskim wziął też udział w kolacji zorganizowanej przez Sulika ${ }^{25}$.

Złudzenia co do postawy Sulika ostatecznie rozwiał jego „napastliwy” artykuł o strajku w Szczecinie w październikowym numerze paryskiej „Kultury”. Do wywiadu dotarła też informacja, że „Bass” przygotowuje „wrogą nam w treści” książkę o Grudniu 1970. Kandydat na tajnego współpracownika w oczach SB przeistoczył się w ,,agresywnego” i ,zdecydowanego" wroga PRL. Jako ,,aktywny działacz reakcyjnej emigracji” Sulik „,współpracuje z ośrodkiem dywersyjnym «Kultura»”. Był też ,powiązany organizacyjnie i działalnością z opozycyjnymi elementami w Polsce (Michnik, Kuroń i inni)”. Ponadto ,skupia i zaczyna przewodzić skrajnie antypolskim elementom emigracyjnym. W działalności antykrajowej ożywia ośrodek «rządu londyńskiego», kierowany obecnie przez «premiera» Kazimierza Sabbata" (przypomniano też, że Sulik był szwagrem Sabbata) ${ }^{26}$.

Zamiast planowanej rozmowy werbunkowej 2 listopada 1976 roku pułkownik Lipowski przygotował postanowienie o wpisaniu Bolesława Sulika do indeksu osób niepożądanych w PRL. W piśmie do Biura Paszportów MSW uzasadniał:

[Sulik] od 1971 r. działa aktywnie przeciwko podstawowym interesom Polski Ludowej. Autor wrogich nam publikacji w paryskiej „Kulturze”. Współautor i scenarzysta filmu, paszkwilu emitowanego przez telewizję brytyjską. Przyjazdy do Kraju wykorzystywał do kontaktowania się, inspirowania wrogich nam elementów, zbierania danych dla ośrodków dywersji ideologiczno-politycznej ${ }^{27}$.

${ }^{24}$ AIPN, 01789/323, Raport płk. S. Lipowskiego z 28 IV 1976 r.; tamże, Tezy płk. H. Wróblewicza do rozmów z „Bassem” z 4 V 1976 r. Zob.: Kto byt kim w drugim obiegu? Stownik pseudonimów pisarzy i dziennikarzy 1976-1989, red. D. Świerczyńska, Warszawa 1995.

${ }_{25}$ AIPN, 01789/323, Szyfrogram „Jaremy” z 22 IX 1976 r.

${ }^{26}$ Tamże, Notatka z 29 X 1976 r. (zał. do wniosku na umieszczenie w indeksie). Zob.: B. Sulik, Robotnicy, s. 65-77. W następnych latach (do 1980) B. Sulik opublikował jeszcze dziesięć tekstów na łamach paryskiej „Kultury”; zob.: M. Danilewicz Zielińska, Bibliografia. „Kultura” (1974-1980), „Zeszyty Historyczne” (1974-1980), działalność wydawnicza (19741980), Paryż 1981, s. 154-155, 182-183, 192.

${ }^{27}$ AIPN, 01789/323, Postanowienie płk. S. Lipowskiego z 2 XI 1976 r. o wpisaniu B. Sulika do indeksu osób niepożądanych w PRL. 
W „teczce” Sulika znajduje się również notatka „Omula” z Budapesztu. Funkcjonariusz wywiadu donosił, iż na początku kwietnia 1977 roku przy przekraczaniu granicy węgiersko-austriackiej, węgierska służba celna zakwestionowała u pisarza Marka Nowakowskiego dwie książki. Jedna $\mathrm{z}$ nich (The Shadow Line Josepha Conrada) zawierała dedykację Sulika wskazującą na jego zażyłą znajomość z Nowakowskim ${ }^{28}$.

Mimo zakazu wjazdu do Polski Sulik nie zerwał kontaktów z działaczami Komitetu Obrony Robotników. O jego krajowych powiązaniach wiedziała SB, sam Sulik nie robił zresztą z tego tajemnicy. Charakteryzując na łamach „Kultury” warszawskie środowisko opozycyjne pisał:

Samo jego istnienie jest demonstracją, a więc pisać o nim należy ostrożnie. [...] Natomiast nie wierzę w obowiązek przemilczania faktu, że ich znam, że bywając w Kraju spotykałem ich, bawiłem się razem i piłem wódkę, że czują do nich sympatię najgłębszą i szacunek ${ }^{29}$.

W końcu maja 1977 roku, kilka miesięcy po utworzeniu Komitetu Obrony Robotników, w MSW opracowano plan śledztwa przeciwko Jackowi Kuroniowi i działaczom KOR, podejrzanym o utrzymywanie kontaktów z zagranicznymi dziennikarzami (w dokumencie wymieniono między innymi Bolesława Sulika). SB zarzucała opozycjonistom przekazywanie zachodnim korespondentom ,fałszywych informacji dot[yczących] stosunków politycznych, społecznych i gospodarczych w Polsce, w tym także

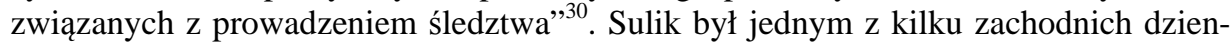
nikarzy, z którymi telefoniczny kontakt utrzymywali Kuroń czy Michnik. Spotykał się również z działaczami bądź współpracownikami KOR podczas ich wyjazdów na Zachód ${ }^{31}$.

W maju 1978 roku Sulik zamierzał ponownie przyjechać do Polski. Gdy konsul odmówił mu udzielenia wizy w sposób „dość obcesowy”, odwołał się do ambasadora Starewicza. Interwencja nie przyniosła jednak skutku. Przed przekazaniem Sulikowi negatywnej decyzji „Jarema” upewnił się w Centrali o podtrzymaniu decyzji o wpisaniu „Bassa” do indeksu osób niepożądanych w PRL. Z Warszawy nadeszło stanowcze potwierdzenie: „Utrzymujemy indeks. Nie pójdziemy z nim [Sulikiem] na żadne rozmowy. Dał dość dowodów swej wrogości, a więc i podstawy do odmowy"32.

Półtora roku później MSW jednorazowo uchyliło zakaz wjazdu do Polski wobec Sulika. Powodem była śmierć i pogrzeb jego drugiej żony — Elżbiety Sulik-Wasilewskiej. Podczas tygodniowego pobytu w kraju „Bass” poddany był „operacyjnej kontroli”. W „Notatce służbowej” pułkownik Wróblewicz podkreślił, iż wypadek losowy (śmierć mieszkającej w kraju żony) ,figurant” wykorzystał do nawiązania „,szerokich kontaktów z czynnie działającym środowiskiem antysocjalistycznym”. Na podstawie inwigilacji oficer wywiadu stwierdził, iż po przylocie do Warszawy Sulik odwiedził Woroszylskiego, u którego spotkał się z Michnikiem. W pogrzebie żony „Bas-

${ }^{28}$ Tamże, Notatka służbowa płk. H. Wróblewicza z 15 IV 1977 r. Sulik był autorem scenariusza do filmowej adaptacji powieści Conrada Smuga cienia z 1976 roku w reżyserii A. Wajdy.

${ }^{29}$ B. Sulik, Oblężeni, s. 6. W 1977 r. za artykuły o Polsce drukowane w „Kulturze” Sulik otrzymał nagrodę paryskiego miesięcznika; zob.: Nagrody „,Kultury”, Kultura 1977 nr 7/8(358/359), s. 40.

${ }^{30}$ Cyt. za: Kryptonim „Gracze”. Stużba Bezpieczeństwa wobec Komitetu Obrony Robotników i Komitetu Samoobrony Spotecznej „KOR” 1976-1981, wybór, wstęp i oprac. Ł. Kamiński, G. Waligóra, Warszawa 2010, s. 237. Zob. też: A. Friszke, Czas KOR-u, s. 205, 224.

${ }^{31}$ Kryptonim „Gracze”, s. 504-505.

${ }^{32}$ AIPN, 01789/323, Szyfrogram „Jaremy” z 10 V 1978 r.; tamże, Instrukcja z 18 V 1978 r. dla ,Jaremy” dot. ,Bassa”. 
sa" uczestniczyło też kilku działaczy Komitetu Obrony Robotników: Adam Michnik, Jacek Kuroń, Jan Józef Lipski, Halina Mikołajska, Jan Lityński, Barbara Toruńczyk, Aniela Steinsbergowa, Ludwik Cohn oraz Wiktor Woroszylski. Jeszcze tego samego dnia Sulik odwiedził Lipskiego, zaś dwa dni później ponownie był u Woroszylskiego oraz spotkał się z Gustawem Gottesmanem i Tadeuszem Konwickim. Odnotowano również, że Sulik był w ambasadzie brytyjskiej, a po wyjściu dzwonił z budki telefonicznej do nieznanego rozmówcy. Gdy wyjeżdżał z Polski na lotnisku żegnał go Michnik. O kontaktach Sulika z ,aktywem” KSS-KOR wywiad zawiadomił Szefa Zwiadu Wojsk Ochrony Pogranicza, sugerując dokonanie kontroli celnej. Sulik zapewne spodziewając się rewizji nie przewoził jednak żadnych „,wrogich” materiałów ${ }^{33}$.

Gdy jesienią 1980 roku Sulik wybierał się do kraju, „Scot” alarmował z Londynu, że emigracyjny publicysta i filmowiec , ,hce złamać zakaz korzystając z obecnej sytuacji i faktu, że wielu jego kolegów i przyjaciół w Polsce zajmuje kierownicze stanowiska w «Solidarności»”. Funkcjonariusz londyńskiej rezydentury wywiadu uważał, że ewentualne zniesienie zakazu wjazdu dla Sulika nie da nic dobrego: „Jest on tu nadal aktywnym organizatorem różnego rodzaju pomocy dla wrogów socjalizmu w Polsce". Gdy w połowie listopada Wajda przyjechał do Londynu na pokaz swoich filmów w Instytucie Kultury Polskiej, ,już w pierwszych słowach po wyjściu z samolotu skierowanych do dyrektora IKP, zapytał «gdzie jest Sulik». Tylko jego prosił na thumacza". Grożąc zerwaniem imprezy wprowadził też Sulika do IKP.

Tak więc sytuacja jest taka - raportował „Scot” — że „Bass”, który jeszcze dwa miesiące temu demonstrował na czele bandy antykomunistów pod Ambasadą, obecnie razem z Wajdą wystąpił na scenie IKP ${ }^{34}$.

W następnych latach Sulik nadal zajmował ,antysocjalistyczną postawę”. W maju 1982 roku Ambasada PRL w Londynie zawiadomiła MSZ, iż stacja ITV w godzinach wieczornych wyemitowała dwugodzinny program Strajk, oparty na wydarzeniach w Gdańsku w sierpniu 1980 roku. Autorem scenariusza był Sulik. W programie nawiązano do strajków na Wybrzeżu w 1970 roku oraz wprowadzenia stanu wojennego i zawieszenia działalności „,Solidarności”. Informację z Londynu MSZ przekazało do wiadomości $\mathrm{MSW}^{35}$.

${ }^{33}$ Tamże, Notatka służbowa płk. H. Wróblewicza z 4 XII 1979 r. Z E. Smoleń-Wasilewską, dziennikarką tygodnika „Film”, Sulik związał się uczuciowo na początku lat 70. W marcu 1977 roku Smoleń-Wasilewska zgłosiła się do Konsulatu Generalnego PRL w Londynie, aby przedłużyć o kolejny rok ważność swojego paszportu. W Wielkiej Brytanii przebywała na leczeniu na zaproszenie Sulika. Przy okazji załatwiania sprawy „rozmowę ogólną” przeprowadził z nią ,Jarema”. Gdy Smoleń-Wasilewska wspomniała, że w przyszłym roku zamierza wraz z Sulikiem powrócić na stałe do kraju, funkcjonariusz z sarkazmem stwierdził, iż pracownicy konsulatu oglądają telewizję oraz czytają prasę. W notatce służbowej dodał, że przebywająca w kraju córka Smoleń-Wasilewskiej bezprawnie pobiera rentę inwalidzką matki. Przyjaciółka Sulika wygadała się również, że w zeszłym roku widziała się z córką w Budapeszcie (w paszporcie rzeczywiście miała stempel węgierski). Na marginesie tej sprawy „Jarema” stwierdził: „,wydaje się niezbędne dokonanie ustaleń z innymi krajami socjalistycznymi, takimi jak CSRS, Węgry, NRD by nie wpuszczali naszych obywateli, posiadaczy paszportów jednokrotnych, którzy wjechali do tych krajów spoza PRL. Gdyby istniało takie porozumienia — podkreślił — wówczas nie byłoby takich wojaży, jak np. Smoleń do Budapesztu”. Z pieczątek w jej paszporcie wynikało zresztą, że ,sporo wraz z «Bassem» podróżują po Europie”; zob.: tamże, Notatka służbowa Jaremy” z 2 III 1977 r. dot. Elżbiety Smoleń-Wasilewskiej.

${ }^{34}$ Tamże, Notatka płk. H. Wróblewicza z 27 XI 1980 r. na podstawie uwag „Scota”.

${ }^{35}$ Tamże, Teleks Ambasady PRL w Londynie do MSZ z 18 V 1982 r. 
W czerwcu 1985 roku zakończone zostało rozpracowanie Sulika. Jeśli celem podjętych dziewięć lat wcześniej działań było „wypracowanie dialogu operacyjnego $\mathrm{Z}$ «Bassem»”, czyli pozyskanie Sulika do współpracy agenturalnej, to zamierzenia tego nie udało się zrealizować. Wywiad nie odnotował co prawda, aby po 1982 roku ,figurant" angażował się w działalność opozycyjną, jednak podporucznik Andrzej Łukiński stwierdził również, iż „nie ma żadnych szans pozyskania «Bassa» do współpracy operacyjnej”. Funkcjonariusz wywiadu dodał, że „w sprawie nie poniesiono wydatków operacyjnych" 36 .

Po raz pierwszy po kilkuletniej przerwie Sulik przyjechał do Polski na przełomie września i października 1985 roku. Podczas pobytu w kraju zbierał materiały do pierwszego odcinka serialu dokumentalnego o historii Polski w XX wieku. Cykl zatytułowany The Struggles for Poland (Walki o Polskę) składał się z dziewięciu odcinków i realizowany był na zlecenie telewizji brytyjskiej, amerykańskiej oraz zachodnioniemieckiej $^{37}$.

W następnym roku Sulik ponownie zamierzał przyjechać do kraju. Tym razem realizował odcinek poświęcony historii Kościoła w Polsce. W rozmowie z dyrektorem Instytutu Kultury Polskiej w Londynie deklarował, że chce „obiektywnie” przedstawić rolę i miejsce Kościoła w Polsce. Zobowiązał się również, że podczas pobytu w kraju będzie się zajmował wyłącznie przeprowadzaniem wywiadów na potrzeby filmu oraz przestudiowaniem dokumentacji dostarczonej przez „Interpress”. Mimo to nie otrzymał zgody na udzielenie wizy ${ }^{38}$.

Choć rozpracowanie Sulika formalnie zakończono w 1985 roku, SB nie przestała się nim interesować podczas jego wizyt w kraju. W trakcie tygodniowego pobytu w Warszawie na początku marca 1988 roku Sulik mieszkał w hotelu „Forum”. Zapewne na podstawie donosów pracownika recepcji, podpułkownik K. Ochociński z Biura „B” MSW zawiadamiał podpułkownika W. Kasprzaka z Departamentu I, że nazajutrz po przyjeździe Sulik o godzinie 9:10 zszedł do recepcji i poprosił o książkę telefoniczną instytucji. Innego dnia wrócił do hotelu o 12:20, „niósł paczkę zapakowaną w papier firmowy Domów Centrum”. W dniu wyjazdu o godzinie 14:05 „Sulik zjechał na hall w towarzystwie dwóch mężczyzn — wszyscy nieśli bagaże”, a po wyjściu z hotelu wsiedli razem do samochodu marki „Polonez” (podał numer rejestracyjny) ${ }^{39}$. Tylko do czego te banalne informacje mogły być przydatne wysokiemu funkcjonariuszowi wywiadu, zwłaszcza pięć dni po wyjeździe Sulika z Polski?

W nowej Polsce Sulik związał się ze środowiskiem Unii Demokratycznej. W 1991 roku zrealizował kontrowersyjny film dokumentalny In Solidarity (W Solidarności), będący swoistym zapisem życia społeczno-politycznego w pierwszym roku po upadku PRL. Latem tego roku wrócił też na stałe do kraju. W 1992 roku wyreżyserował film Generat (wywiad-rzeka z Wojciechem Jaruzelskim). W 1993 roku z rekomendacji UD wszedł do Krajowej Rady Radiofonii i Telewizji, której był przewodniczącym w latach 1995-1999. Od roku 2000 do 2003 zasiadał w radzie nadzorczej Telewizji Polskiej. Sulik był jednym z najważniejszych świadków w aferze Rywina. Jako jedyna osoba spoza „Agory” przed ujawnieniem sprawy wysłuchał nagrania rozmowy Adama Mich-

${ }^{36}$ Tamże, Notatka końcowa ppor. A. Łukińskiego z 19 VI 1985 r. sprawy SMW nr XI/720/76 krypt. „Bass”

${ }^{37}$ Tamże, Pismo Biura Paszportów MSW z 8 I 1986 r. do Departamentu I MSW.

${ }^{38}$ Tamże, Szyfrogram „Briga” z Londynu z 30 IX 1986 r.; tamże, Pismo Departamentu I z 8 X 1986 r. do Departamentu IV MSW.

${ }^{39}$ Tamże, Pismo ppłk. K. Ochocińskiego z 16 III 1988 r. do ppłk. W. Kasprzaka. 
nika z Lwem Rywinem. Zeznając przed sejmową komisją śledczą kwietniu 2003 roku zapewniał, iż nie wierzy, żeby za korupcyjną propozycją Rywina stał premier Leszek Miller. Bronił także prezesa TVP Roberta Kwiatkowskiego ${ }^{40}$.

Bolesław Sulik zmarł 22 maja 2012 roku w wieku 83 lat $^{41}$.

\section{BOLESŁAW SULIK-LIAISON OFFICER FROM LONDON}

Bolesław Sulik (1929-2012), an emigration publicist, script writer and filmmaker, from the second half of the 60 's of the $20^{\text {th }}$ century visited Poland several times. He cooperated with leading Polish directors Andrzej Wajda nad Jerzy Skolimowski. In the 70's he established contact with the budding opposition, Adam Michnik among others. He became the unofficial liaison officer between the countrys' opposition (the Workers' Defence Committee) and Kultura in Paris. The Security Service intended to enlist him. In 1976 the candidate for a secret collaborator was listed in the index of persona non grata in the People's Republic of Poland.

KEY WORDS: Intelligence in the People's Republic of Poland towards emigration; Bolesław Sulik; Parisian Kultura; political opposition in the People's Republic of Poland.

${ }^{40}$ Chcę sprzedawać polskie talenty [z B. Sulikiem rozm. T. Sobolewski], Kino $1991 \mathrm{nr} 10$, s. 3-7; Od kryzysu do kryzysu [z B. Sulikiem rozm. B. Janicka i A. Kołodyński], Kino $1994 \mathrm{nr}$ 11, s. 4-6, 40; B. Sulik, Sprawozdanie z działalności Krajowej Rady Radiofonii i Telewizji, Kino (dod. Reżyser), $1999 \mathrm{nr}$ 6, s. 1-3. O przesłuchaniach przed sejmową komisją śledczą obszernie informowała prasa, m.in.: „Gazeta Wyborcza” czy „Rzeczpospolita”.

${ }^{41}$ Bolestaw Sulik nie żyje, Gazeta Wyborcza 2012 nr 119, s. 3; T. Glazer, Bolek, Dziennik Polski (Londyn) 2012 nr 120, s. 9. 